\title{
Legal Forms Activity of Technology Transfer Network on Example in Aerospace Industry
}

\author{
Evgen Novikov
}

Junior Research Fellow of the Scientific and Research Institute

of Providing Legal Framework for the Innovative Development of National Academy

of Law Sciences of Ukraine

(Kharkiv, Ukraine)

E-mail: evgeniy.novikov90@gmail.com

\begin{abstract}
At the time of the existence of economic, strategic and technological needs in creating a national aerospace sector in many developing countries. International cooperation projects in the aerospace industry are estimated at US $\$ 3$ trillion. Ukraine belongs to the countries that generate technology transfer, exporting its technology to developing countries. The purpose of the paper is to determine the legal forms of international and domestic technology transfer networks in the aerospace industry, to clarify the principles of their construction and to establish the features of contractual forms of relations in such networks between their participants.
\end{abstract}

Keywords: technology transfer; technology transfer network; aerospace industry; legal forms.

\section{Правові форми діяльності мереж трансферу технологій, на прикладі аерокосмічної індустрїі}

\section{Новіков, Свген Андрійович}

Молодший науковий співробітник,

Науково-дослідний інститут правового забезпечення інноваційного розвитку

Національної академії правових наук України

(Харків, Україна)

На часі існування економічних, стратегічних та технологічних потреб у створенні національного аерокосмічного сектора у багатьох краӥнах, що розвиваються. Міжнародні проекти співпраці у аерокосмічній індустрії оцінюються у трильярди доларів США. Україна відноситься до держав, які генерують трансфер технологій, експортуючи свої технологї до країн, щчо розвиваються. Мета статті полягає у визначенні правових форм міжнародних $і$ вітчизняних мереж трансферу технологій в аерокосмічній індустрії, з'ясуванні принципів їхньої побудови та встановленні особливостей договірних форм відносин у таких мережах між їхніми учасниками.

Ключові слова: трансфер технологій; мережа трансферу технологій; аерокосмічна індустрія; правові форми.

(C) Novikov, Evgen, 2018 
Received: January 8, 2018; accepted: February 1, 2018

Advanced Space Law, Volume 1, 2018: 74-83.

https://doi.org/10.29202/asl/2018/1/9

\section{Ветуп}

У наш час починається принципово новий етап інтеграції України до європейської та світової спільноти, в якому пріоритетним напрямом стає вихід на ринки ЄС та інших країн для пошуку партнерів для спільної інноваційної діяльності та комерціалізації об’ єктів права інтелектуальної власності. У статті «Підгрунтя для підтримки передачі країнам що розвиваються аерокосмічних знань через спільні проекти» («A Framework to Support Aerospace Knowledge Transfer to Developing Countries via Collaborative Projects») автори наголошують на існуванні економічних, стратегічних та технологічних потреб у створенні національного аерокосмічного сектора у багатьох країнах, що розвиваються [Homoud \& Al-Ashaab, 2017]. Міжнародні проекти співпраці у аерокосмічній індустрії оцінюються у трильярди доларів США. Україна відноситься до держав, які генерують трансфер технологій, експортуючи свої технології до країн, що розвиваються.

Загалом трансфер технологій передбачає вертикальне просування об'єктів комерціалізації, а весь інноваційний цикл найчастіше зосереджується в одній науковій організації. Результати науково-дослідної діяльності передаються у вигляді знань, технологій, методів виробництва, зразків виробництва й складових об'єктів технологій від підрозділу до підрозділу та за найбажаніших умов надалі безпосередньо суб'єктам їхньої комерціалізації. Пошук таких суб'єктів та інвесторів допомагають здійснювати центри трансферу технологій, об’ єднуючись у велику мережу трансферу технологій для інформаційної консолідації власних зусиль.

Мета статті полягає у визначенні правових форм міжнародних і вітчизняних мереж трансферу технологій на прикладі аерокосмічної індустрії, з'ясуванні принципів їхньої побудови та встановленні особливостей договірних форм відносин у таких мережах між їхніми учасниками.

\section{Аналіз останніх досліджень}

В Україні питанням створення й функціонування мереж трансферу технологій присвячені наукові дослідження В. С. Лисенко, С. О. Сгоров, В. Я. Козаченко, Р. В. Ободець, Я. В. Заіка, В. К. Хаустов та інших. Проблемам правового регулювання організаційно-правових форм присвячено чимало наукових праць правників, зокрема, В. І. Борисової, І. Ф. Коваль, О. В. Дзери, Н. В. Козлової, Н. С. Кузнєцової, І. М. Кучеренко, А. П. Сергєєва, І. В. Спасибо-Фатєєвої, Є. О. Суханова, О. М. Віннік, Д. В. Задихайла, О. Р. Кібенко, В. С. Мілаш, Н. О. Саніахметової, В. С. Щербини, К. О. Кочергіної та інших у межах обраних авторами напрямів досліджень. Питаннями дослідження окремих договірних форм регулювання відносин займалися вчені різних галузей права зарубіжної та вітчизняної науки, зокрема, про правову природу договору писали М. Ф. Казанцев, В. В. Іванов, С. Ю. Головіна, І. І. Лукашук, К. К. Афанасьєв; контрак- 
ту — I. І. Банасевич, О. А. Беляневіч, Ю. Г. Басін; мирових угод - Г. Ф. Шершеневич, В. В. Прохоренко, Ю. Д. Притика; примирення — М. Е. Некрасова. Однак дослідження договірних організаційно-правових форм мереж трансферу технологій до цього часу ще не було проведено.

\section{Результати дослідження}

За визначенням Володимира Лисенка мережею трансферу технологій є горизонтальні методи просування на основі партнерства й кооперації, при якому провідна установа $\epsilon$ генератором інновацій, а функції зі створення та просування інноваційної технології розподілені між іншими учасниками комерціалізації технологій [Лисенко \& Сгоров, 2010].

Проаналізувавши правову природу вітчизняних і зарубіжних мереж трансферу технологій, принципи побудови та функції, можна виділити їхні головні кваліфікуючі ознаки:

1. Мета — консолідація інформаційних ресурсів у технологічній сфері та координація дій в інноваційній сфері;

2. Учасниками мережі є два або більше суб'єктів господарювання, пов'язаних з інноваційною діяльністю та / або трансфером технологій;

3. Обов'язкова наявність власної електронної платформи, на якій розміщуються технологічні профілі або технологічні запити та пропозиції;

4. Наявність суб'єкта, який здійснює організацію та управління діяльністю мережі, а саме адміністратора, координатора;

5. Виникнення двох видів правовідносин у зв'язку із функціонуванням мережі: зовнішніх відносин із клієнтами-споживачами інноваційних продуктів (технологій) $\mathrm{i}$ внутрішніх відносин у середині мережі між учасниками, які, у свою чергу, поділяються на підвиди: організаційні (щодо створення мережі, управління та участі) та відносини, пов’язані з трансфером технологій (у широкому і вузькому значенні);

6. Об'єднання учасниками мережі немайнових об'єктів та / або інформації про них;

7. Відсутність обов'язкового об'єднання майна та у зв'язку з цим нівелювання необхідності управління ним.

Звертаючись до практики міжнародної науково-технічної кооперації, проаналізуємо, у яких саме організаційно-правових формах існують найпоширеніші та найефективніші мережі трансферу технологій.

Щодо мереж трансферу технологій країн $Є C$, то відзначимо, що частина 3 них створена у формі асоціації. Так, European Business \& Innovation Centre Network (Європейська мережа бізнес-інноваційних центрів) у ст. 3 свого статуту зазначає, що «Асоціація є міжнародною неприбутковою організацією. Усі кошти, доступні Асоціації, будуть спрямовані на досягнення цілей Асоціації. Ї̈і основним завданням є сприяння розвитку центрів бізнесу та інновацій як у межах, так і поза межами Європейського Союзу (СC)» [Statutes of European Business, 2018].

На офіційному сайті «Асоціації європейських фахівців з трансферу науки і технологій» (ASTP) («The Association of European Science and Technology Transfer Professionals») зазначається, що «ASTP $є$ неприбутковою організацією, що займається передачею знань між університетами та промисловістю» [ASTP-Proton, 2017]. Асоціація була створена в 2000 році групою провідних практиків, більш ніж 800 членами 341 країни. 
Проект Європейського Союзу «Європейська мережа підприємств» («European Enterprise network», EEN) є найбільшим у світі бізнес-співтовариством, яке об'єднує більш ніж 600 організацій із підтримки інтернаціоналізації підприємництва, залучення інвестицій і трансферу технологій у 63 країнах світу. Учасниками мережі є бізнес-асоціації, торговельні палати, відповідні державні установи, бізнес-акселератори, інвестиційні банки, технопарки та наукові інститути. Кількість фахівців, які безпосередньо працюють над реалізацією цілей даного проекту, перевищує 4500 осіб. Усі учасники мережі об’єднуються в консорціуми за регіональною ознакою. Основні їхні функції включають надання консультативних послуг компаніям країни / регіону, які вони представляють, щодо доступу на ринок ЄC та інших країн EEN, щодо наявних інструментів фінансової допомоги, питань захисту прав інтелектуальної власності, комерціалізації інновацій тощо. «Європейська мережа підприємств» створена Європейською комісією у 2008 році. На загальноєвропейському рівні «Європейська мережа підприємств» виступає проектом Європейського Союзу, що реалізується в рамках Програми ЄС «Конкурентоспроможність підприємств малого та середнього бізнесу (COSME)», а на національному рівні учасники мережі трансферу технологій об'єднуються в консорціуми за регіональною ознакою [European, 2018].

32008 року в Україні започаткований пілотний проект «Українська мережа трансферу технологій» (UTTN), що реалізується Академією технологічних наук України спільно з Міністерством освіти і науки України. Проект грунтується на підставі Меморандуму «Про створення та розвиток Національної мережі трансферу технологій NTTN державними та недержавними суб'єктами трансферу технологій». Проект передбачає створення мережі, що направлена на консолідацію інформаційних ресурсів державних, громадських, приватних інноваційних структур України, підприємств, установ та організацій в єдину мережу трансферу технологій та подальшу інтеграцію НМТТ до європейської мережі EEN [Національна, 2013]. Як зазначено на офіційному сайті «Національної мережі трансферу технологій», вона $є$ «колективною структурою, учасники якої здійснюють спільну діяльність без об’єднання своїх вкладів. Юридичні особи стають учасниками шляхом підписання з Координатором Договору приєднання до Національної мережі трансферу технологій NTTN» [Національна, 2013].

Інша вітчизняна мережа «Українська інтегрована система трансферу технологій» буда створена на засадах європейської мережі EEN та російської мережі RTTN. Відповідно до свого Регламенту вона $є$ самостійною мережевою структурою у формі об 'єднання організацій, які працюють у сфері інновацій і трансферу технологій, та призначена для накопичення та забезпечення оперативного обміну інформацією між розробниками і споживачами інноваційної продукції. Головною метою функціонування каналів трансферу є створення умов для просування інформаційних технологій, високотехнологічної продукції та послуг на внутрішній та міжнародні ринки, скорочення витрат підприємств-розробників технологій на пошук замовників і партнерів у бізнесі, забезпечення юридичної чистоти відповідних угоді захист прав інтелектуальної власності авторів технологій [Українська, 2017]. «Українська інтегрована система трансферу технологій» була створена на замовлення Державного агентства 3 питань науки, інновацій та інформатизації України, а функцію іiї координатора виконує ДП «Центр науково-технічної інформації та сприяння інноваційному розвитку України (Укртехінформ). Учасником цієї мережі може стати будь-яка організація, яка здійснює свою діяльність у сфері трансферу технологій, має клієнтську базу та можливість надавати своїм клієнтам 
послуги, визначені Регламентом УІСТТ, шляхом підписання Договору про членство в Мережі з Координатором.

Проаналізувавши організаційні форми існування іноземних і вітчизняних мереж, можна дійти висновку, що в основі їхньої роботи лежать різні форми здійснення спільної діяльності ії учасників і партнерів. Така організація діяльності може існувати у двох формах:

По-перше, учасники можуть обрати організаційно-правову форму функціонування мережі як певного колективного утворення без створення юридичної особи (просте об’єднання осіб) шляхом укладення договору, на підставі якого вони об'єднують свої зусилля та розподіляють обов'язки для забезпечення ефективного просування технологій до їхніх споживачів. Таким прикладом виступають мережі, створені на виконання проекту (усі вітчизняні мережі, польська мережа STIM та EEN, як проект СC, що реалізується в рамках програми «COSME»).

По-друге, діяльність учасників може бути спрямована на співробітництво в межах об'єднання юридичних осіб як самостійного суб'єкта права. На прикладі розглянутих мереж ЄС для них обрана організаційно-правова форма асоціації як об'єднання учасників, яке може бути як комерційним, так і ні. Тож можна виділити такі організаційно-правові форми діяльності мережі трансферу технологій: договірні (проектний підхід), інституційні (суб'єктний підхід).

У господарському та цивільному праві традиційно розглядаються теорії про договірні форми відносин і організаційно-правові форми підприємств (юридичних осіб). У вітчизняній літературі, як правило, використовуються різні форми договірного регулювання відносин, але серед інших форм завжди найбільшу увагу приділяють саме договору.

Основними договірними формами, що використовуються під час проведення робіт із досліджень і розробок за європейськими рамковими програмами, виступають грантовий договір та договір консорціуму.

Консорціум (від лат. consortium - співучасть, товариство) - форма об 'єднання організацій, яке має тимчасовий характер, із метою досягнення наперед визначеної цілі, яка не $є$ протиправною з точки зору чинного законодавства. У книзі «Експортні консорціуми в країнах, що розвиваються» («Export Consortia in Developing Countries») автори на прикладах засвідчили вагому роль експортних консорціумів та ключові фактори, що впливають на їх успішну співпрацю. Емпіричні дані що наводять автори підтверджують, що консорціуми можуть відігравати важливу роль у країнах, що розвиваються, i, як наслідок, підвищувати рівень міжнародної конкурентоспроможності цих країн [Antoldi et al., 2011].

Для отримання гранту на проведення міжнародних наукових досліджень від Європейської комісії (далі — СК) науковим організаціям необхідно утворити консорціум на підставі відповідного договору. Договір консорціуму є юридичним документом, у якому закріплена угода між собою всіх партнерів-учасників консорціуму для можливості подання спільних заявок на отримання гранту від ЄК на проведення міжнародного наукового дослідження із укладенням з СК грантового договору. Майже всі проекти рамкових програм ЄС повинні мати такий договір. Однак Єврокомісія ніколи не виступає партнером такого проекту й не відповідає за зміст цього договору.

Існує велика кількість можливих зразків договору консорціуму, проте до основних істотних умов відносять лише ті, які розкривають основні характеристики відносин 
його учасників: а) внутрішню організацію консорціуму; б) розподіл фінансових коштів консорціуму; в) права на інтелектуальну власність і додаткові правила з ії поширення й використання; г) угоду про порядок розгляду внутрішніх спорів [Програма, 2015]. У науковій та інноваційній сфері утворення консорціуму часто має об'єктивні передумови: наявність державної чи міждержавної програми, яка припускає грантове фінансування за умови відповідності підвищеним кваліфікаційним вимогам. На нашу думку, основою консорціумних відносин виступають кваліфікаційні показники діяльності суб'єктів наукової діяльності, спеціалізація яких відповідає предмету досліджень. Вони не зумовлені особливими попередніми відносинами довіри один до одного, однак у разі наявності вдалого спільного досвіду рішення щодо укладення договору консорціуму, безумовно, приймається впевненіше.

На відміну від європейських мереж, які створені та діють на підставі договору консорціуму або у формі юридичної особи (асоціації), домінуючою організаційно-правовою формою роботи вітчизняних мереж трансферу технологій $є$ договірна шляхом здійснення спільної діяльності щодо конкретного проекту.

Частина 2 ст. 1130 ЦК України вказує на існування двох різновидів договору про спільну діяльність - договір простого товариства (на основі об'єднання вкладів учасників) і договір про спільну діяльність, що не передбачає об’єднання вкладів учасників [Цивільний кодекс, 2003]. У сучасній вітчизняній юридичній літературі також найбільш поширеним є підхід до визначення двох основних організаційно-правових форм здійснення спільної діяльності в Україні [Луць, 2008]:

1. Учасники можуть обрати організаційно-правову форму їхньої спільної діяльності, що не передбачає створення юридичної особи;

2. Спільна діяльність учасників може бути спрямована на здійснення співробітництва в межах самостійного суб'єкта права — юридичної особи.

У першому випадку, на думку Володимира Луця, відносини, що виникають між учасниками, оформляються в договорі про спільну діяльність, який $є$ юридичним фактом або підставою виникнення зобов'язання за спільною діяльністю і містить усі істотні та інші умови взаємовідносин сторін. У другому випадку на підставі правових вимог, що пред'являються до даного виду спільної діяльності, учасникам необхідно укласти установчий (засновницький) договір, який не тільки регулює їхню спільну діяльність, а й визначає правовий статус створеної ними 3 цією метою юридичної особи [Луць, 2008].

Велика перевага спільної діяльності як форми об'єднання суб'єктів господарювання з метою отримання прибутку, порівняно $з$ господарськими товариствами, пов'язана із можливістю встановлювати права й обов'язки договором, на власний розсуд, з огляду на ситуацію та конкретні інтереси сторін. У договорі про спільну діяльність сторони можуть визначати додатково відповідальність за невиконання зобов'язань, порядок вирішення спорів, обов'язок утримуватися від певних дій та інше. Законодавство України надає сторонам право самим встановлювати умови договору про спільну діяльність, зокрема координацію спільних дій учасників або ведення їхніх спільних справ, правовий статус виділеного для спільної діяльності майна, покриття витрат і збитків учасників, їхню участь у результатах спільних дій, підстави припинення спільної діяльності та інші умови.

До особливостей, що дозволяють відмежувати договір про спільну діяльність від інших юридичних договірних конструкцій, ми пропонуємо віднести такі: 
1. Наявність загальної мети. На відміну від інших договорів, у яких інтереси контрагентів протилежні і взаємоспрямовані (наприклад, у договорі купівлі-продажу продавець зацікавлений в отриманні привабливої ціни, а покупець - у придбанні товару), інтереси сторін договору про спільну діяльність завжди збігаються і задовольняються за допомогою спільних дій. Єдність інтересів усіх учасників договору обумовлена спільністю мети, досягнення якої однаково важливо для всіх сторін. Задоволення інтересів будь-якого учасника договору відбувається не за рахунок, а поряд із задоволенням інтересів усіх інших учасників.

2. Фідуціарність спільної діяльності. Досягнення спільної мети неможливе інакше, ніж шляхом узгоджених дій, єдиних за своїми правовими наслідками для всіх учасників. Тому при реалізації такого договору всі сторони беруть особисту участь, що, у свою чергу, надає регульованим договором відносинам довірчий (фідуціарний) характер, що позначається, наприклад, на особливостях припинення договору про спільну діяльність.

3. Переважно багатосторонній характер. Єдність інтересів і наявність спільної мети, що досягається в результаті спільної діяльності, дають змогу врегулювати в договорі відносини необмеженого кола учасників господарського обороту, кожен із яких стає самостійною стороною за договором. Факт, що в договорі про спільну діяльність може бути всього два учасники, не впливає на висновок про багатосторонній характер такого договору, оскільки це не скасовує принципової можливості збільшення числа учасників шляхом прийняття нових осіб як самостійних сторін.

4. Відсутність праеосуб'єктності у створеного на основі договору про спільну діяльність колективного утворення. Здійснення спільної діяльності обумовлює виникнення своєрідного колективу представників суб'єктів цивільного права, об'єднаного спільною метою. Однак таке колективне утворення саме по собі не стає самостійним учасником господарського обороту й тому не набуває властивостей правосуб'єктності у класичному розумінні, не володіє самостійними правами та не несе майнових обов'язків і майнової відповідальності, окрім спільного оподаткування. Це відрізняє створене на основі договору про спільну діяльність колективне утворення від юридичної особи. Наслідком відсутності правосуб'єктності в такого колективного утворення є відсутність вимог заборони на участь особи одночасно в декількох договорах про спільну діяльність, подібній тій, яка встановлена ч.2ст. 119 ЦК України та ч. 2 ст. 66 ЗУ «Про господарські товариства» щодо повного товариства [Цивільний кодекс, 2003].

5. Тривалий характер відносин. Із правової природи спільної діяльності випливає, що договір про таку діяльність опосередковує вчинення цілого комплексу різних дій, розтягнутих у часі (правочинів, інших юридичних і фактичних дій).

6. Регулювання не тільки майнових, а й організаційних відносин. Спільна діяльність для досягнення спільної мети повинна мати взаємоузгоджений характер. Тому у зміст такого договору обов'язково входять питання з управління загальними справами колективного утворення.

Якщо порівняти особливості договору про спільну діяльність з ознаками мережі трансферу технологій, то можна дійти висновку про їхню схожість, із певними винятками, а саме: 
1. Наявність загальної мети мережі, консолідація інформаційних ресурсів у технологічній сфері, яка може й не співпадати з метою кожного учасника, але досягається завдяки передачі інформації про суб'єкта та його пропозиції або запити в інноваційній сфері;

2. Багатосторонній характер, причому завжди більше ніж двох учасників;

3. Відсутність довірчих відносин, або об’єднання на основі об'єктивних характеристик самого суб'єкта, його діяльності та продуктів;

4. Тривалий характер відносин;

5. Регулювання перш за все організаційних відносин;

6. Відсутність право-суб'єктності у класичному розумінні.

Водночас наведені особливості трансферу технологій $є$ загальними і для застосування при оформленні мережі трансферу технологій і договору консорціуму, який впорядковує перш за все організаційні відносини його учасників стосовно передачі й розподілу прав інтелектуальної власності на об'єкти технології. Договори про спільну діяльність і консорціуму мають чимало спільного: багатосторонні, для досягнення спільної мети, потребують об’єднання дій i, можливо, певного майна або немайнових прав. Водночас варто виділити низку особливостей консорціум- них відносин, які виділяють його серед загального кола договорів про спільну діяльність, й особливо від простого товариства.

На наш погляд, договір консорціуму треба визначати саме як організаційний договір, основна мета укладення якого полягає в об’єднанні дій, а не майна. У сфері інновацій і трансферу технологій такі договори найчастіше оформлюють кооперацію суб'єктів наукової діяльності для проведення спільних досліджень, у результаті яких вони одержують права на об’єкти інтелектуальної власності та технології або на підставі факту їх створення, або на ліцензійних умовах, у разі якщо майнові права на такі об’єкти належать іншим учасникам консорціуму. Однак у будь-якому разі відбувається розширення кола суб'єктів, які мають права використання таких нематеріальних об'єктів, а отже, досягається основна мета мережі трансферу технологій — передача майнових прав на об’єкти інтелектуальної власності та технології. Майновий аспект договірних відносин консорціуму часто полягає у площині порядку використання коштів, які надійшли як гранти або благодійні внески, або як надходження від надання послуг, пов'язаних із трансфером технологій (допоміжних і супутніх).

Як вже було зазначено, утворення консорціуму часто має зовнішні об’єктивні причини - відповідати підвищеним вимогам (кадровим, кваліфікаційним, матеріально-технічним, щодо досвіду), які необхідні для одержання фінансування або доступу на ринок. Цим пояснюється факт, що без проведення юридичного об'єднання відповідних вкладів усі показники діяльності учасників консорціуму об'єднуються та вважаються єдиними (зокрема, щодо майна, наукових працівників, наукових результатів, матеріальної бази та іншого). Отже, при консорціумі юридично не відбувається зміни правового режиму майна та юридичних основ діяльності працівників його учасників, однак при цьому для третіх осіб вони визначаються як такі, що перебувають у спільній власності або у спільному користуванні. При цьому в консорціумі учасники не утворюють спільне майно, як це має місце в договорі простого товариства, де відповідно до ч. 1 ст. 1134 Цивільного кодексу України внесене учасниками майно, яким вони володіли на праві власності, а також вироблена в результаті спільної діяльності продукція та одержані від такої діяльності плоди й доходи $є$ спільною частковою власністю учасників, а внесене учасниками майно, яким вони володіли на підставах інших, ніж право власності, використовується в 
інтересах усіх учасників і є їхнім спільним майном [Цивільний кодекс, 2003]. Наслідками наведених особливостей консорціуму стає більший ступінь незалежності його учасників під час реалізації спільної мети, а також збереження права самостійного розпорядження належним йому майном і трудовими ресурсами.

Отож договір консорціуму, вважаємо, є різновидом договору про спільну діяльність, який має відмінні характеристики від простого товариства, а тому може бути визначений у гл. 77 розділу III Цивільного кодексу України як окремий поіменований договір для здійснення спільної діяльності. Договори про спільну діяльність найбільшою мірою відповідають економічній суті відносин щодо реалізації проектів, а тому залежно від конкретних умов об'єднання зусиль його учасників становлять основу діяльності мережі трансферу технологій на сучасному етапі розвитку інформаційних відносин і технологій.

\section{Висновки}

Вивчення діючих в Україні та на території СС мереж трансферу технологій дали змогу встановити їхні ознаки як правового явища та визначити їхні правові форми. Утворення мережі трансферу технологій як самостійного суб'єкта господарювання найчастіше відбувається як об'єднання підприємств, як комерційного, так і некомерційного характеру. Однак інституційні форми мереж трансферу технологій є занадто «традиційними» для регулювання нових і складних відносин у сфері трансферу технологій. Головними передумовами виникнення інституту юридичної особи історично була «тріада елементів», які відбивали потреби фізичних осіб у сфері господарського обороту: необхідність об’єднання майна учасників господарської організацій управління цим майном та самостійна майнова відповідальність такої організації, відокремлена від відповідальності іiі учасників. Через особливу інформаційну природу мереж трансферу технологій та організацію їхньої діяльності, а саме: об'єднання нематеріальних об'єктів та / або інформації про них, спільних дій учасників та їхньої мережевої організації співпраці, - необхідність об’єднання майна та управління ним у межах такого колективного утворення фактично нівелюється. На наш погляд, інформація стає тим головним об'єктом, заради одержання та володіння яким відбувається утворення мережі трансферу технологій. Трансформація потреб суб'єктів при утворенні останньої зумовлює зникнення класичних ознак юридичної особи в діяльності такої мережі. На цій підставі вважаємо, що створення мереж трансферу технологій в правовій формі юридичної особи в перспективі є незатребуваним і неефективним через інформатизацію та глобалізацію відносин на міжнародному рівні.

Отже, актуальною організаційно-правовою формою мереж трансферу технологій в $\epsilon$ договірна з укладенням договорів про спільну діяльність із метою реалізації спільного проекту. На сучасному етапі розвитку господарських відносин відбулася модифікація договорів про спільну діяльність (зокрема, договори консорціуму), які вже враховують задачі, функції та особливості діяльності мереж трансферу технологій та основний об’єкт відносин між ії учасниками - інформацію.

Отже, мережа трансферу технологій, в аерокосмічній індустрії - це колективне утворення (зі створенням або без створення юридичної особи) професійних учасників ринку трансферу технологій із метою консолідації інформаційних ресурсів у технологічній сфері шляхом об'єднання нематеріальних об'єктів та/або інформації про них на 
електронному майданчику, спільних дій учасників та їхньої мережевої організації співпраці, у результаті діяльності якого відбувається передача прав інтелектуальної власності від авторів (розробників) до суб'єктів господарської діяльності, які використовують їхні об'єкти при виробництві товарів, виконанні робіт, наданні послуг.

\section{Література}

Луць, Володимир. Контракти в підприємницькій діяльності: навчальний посібник. Київ: Юрінком Інтер, 2008.

Національна мережа трансферу технологій. 2013. http://nttn.org.ua/

Програма Європейського Союзу «Горизонт 2020». Рекомендації для нових учасників програми. 2015. https://www.stu.cn.ua/media/files/pdf/Rekomend_Horizont_2020.pdf

Українська інтегрована система трансферу технологій. 2017. http://untt.com.ua/

Цивільний кодекс України від 16.01.2003 № 435-IV. Відомості Верховної Ради України. 40-44, 2003. Ст. 356

Antoldi, Fabio, Daniele Cerrato, and Donatella Depperu. Export Consortia in Developing Countries. Successful Management of Cooperation Among SMEs. Verlag: Springer Berlin Heidelberg, 2011.

ASTP-Proton. 2017. https://www.astp-proton.eu/

European Enterprise network. 2018. https://een.ec.europa.eu/

Homoud, Al-Shaigi and Ahmed Al-Ashaab. A Framework to Support Aerospace Knowledge Transfer to Developing Countries via Collaborative Projects. International Journal of Economics and Management Systems, Vol. 2, 2017: 111-120.

Statutes of European Business \& Innovation Centre Network. Official site EBN. https:// ebn.eu/downloads/EBN\%20Statutes\%20-\%202005.pdf

\section{References}

Luts, Volodymyr. Kontrakty v pidpryiemnytskii diialnosti: navchalnyi posibnyk. Kyiv: Yurinkom Inter, 2008.

Natsionalna merezha transferu tekhnolohii. 2013. http://nttn.org.ua/

Prohrama Yevropeiskoho Soiuzu «Horyzont 2020». Rekomendatsii dlia novykh uchasnykiv prohramy. 2015. https://www.stu.cn.ua/media/files/pdf/Rekomend_Horizont_2020.pdf

Ukrainska intehrovana systema transferu tekhnolohii. 2017. http://untt.com.ua/

Tsyvilnyi kodeks Ukrainy vid 16.01.2003 № 435-IV. Vidomosti Verkhovnoi Rady Ukrainy. 40-44, 2003. St. 356

Antoldi, Fabio, Daniele Cerrato, and Donatella Depperu. Export Consortia in Developing Countries. Successful Management of Cooperation Among SMEs. Verlag: Springer Berlin Heidelberg, 2011.

ASTP-Proton. 2017. https://www.astp-proton.eu/

European Enterprise network. 2018. https://een.ec.europa.eu/

Homoud, Al-Shaigi and Ahmed Al-Ashaab. A Framework to Support Aerospace Knowledge Transfer to Developing Countries via Collaborative Projects. International Journal of Economics and Management Systems, Vol. 2, 2017: 111-120.

Statutes of European Business \& Innovation Centre Network. Official site EBN. https:// ebn.eu/downloads/EBN\%20Statutes\%20-\%202005.pdf 